\title{
Intellectual Fads in Political Science: The Cases of Political Socialization and Community Power Studies
}

\author{
Yali Peng, University of Oregon*
}

In his 1988 article in $P S$, "Separate Tables: Schools and Sects in Political Science," Gabriel Almond (1988) claimed that political science "has turned into a set of disembodied specialties lacking in linkage to politics and public policy." Such is the state of the discipline which many observers hold to be true. ${ }^{1}$ The discipline's alleged disintegration and lack of touch with political reality is the concern of many practitioners. In answering the question, "What issues should concern us as political scientists over the next ten years?" Almond believed that among the priorities should be the problem of the unity of the discipline and the relationship among its parts (Almond 1990).

As a fragmented discipline, political science has its special characteristics. One of these, which has not been adequately studied, yet which I believe is closely related to the fragmented characteristics of the discipline, is the rapid rise and fall of various methods, approaches, and fields of study"intellectual fads."

As Wiarda points out:

The distinct fields within the political science discipline tend to rise and fall in popularity, however, depending on a variety of circumstances including levels of theoretical sophistication, trends in worldwide or U.S. history, and newspaper headlines - and not excluding intellectual fads and fashions (Wiarda 1985).

According to Webster's New World Dictionary, fad means "a custom, style, etc. that many people are interested in for a short time."'2 Intellectual fads, as we understand them, refer to the situation in which an approach or a field of study rises quickly and attracts much attention, but loses popularity after a period of time and declines sharply. Finding answers to such questions as why fads exist in political science and how the phe- nomenon reflects the characteristics of the discipline in general may help us gain more understanding of political science as a systematic inquiry of politics and the relationship between academic efforts and the real political world. Furthermore, the findings may help us understand the phenomenon of "fads" in general in scientific studies.

\section{Political Socialization and Community Power Study}

Political socialization and community power were chosen as the objects of investigation for several reasons. First, both categories are fields of study, rather than approaches or methods, which makes the investigation easier to manage. Second, both fields originated in the $1950 \mathrm{~s}$, developed in the $1960 \mathrm{~s}$, reached their heights in the 1970s, and declined in the 1980s. Third, data on literature in both fields are readily available, as the Social $S$ Cience Index (SSI) lists both political socialization and community power as independent categories.

\section{Political Socialization}

In 1959, Herbert Hyman published Political Socialization. Hyman's concern was that, although the study of socialization and learning had been flourishing in social psychology, almost no attention had been given to politics "as a consequence of socialization", (Hyman 1959, 26). This implied, complained Hyman, that politics had been regarded as a sudden phenomenon of adult life, quite different from other developmental processes that had been studied over and over again (Hyman 1959, 26). Hyman's purpose was to alert political scientists to this important field of inquiry.

As a result of Hyman's work, political socialization research gained academic prominence in the following two decades. ${ }^{3}$ Hundreds of articles and dozens of books were published. The 1968 Biographical Directory of the American Political Science Association for the first time listed political socialization as a subdivision, which "did not even exist in the general vocabulary of political scientists ten years earlier" (Greenstein and Polsby 1975). According to Schonfeld, political socialization was the 13th most popular subfield out of 27 (1971).

In the early 1970 s, it seemed that the study of political socialization was unfolding and ascendant, far from reaching its limit. One observer in 1975 remarked that "during the last several years few fields of political science have experienced as great an expansion as the field of political socialization" (Volgyes 1975).

Nevertheless, the study of political socialization did not rise without doubt or uncertainty. In fact, it had already experienced some setback as early as 1975 (Gilberg 1975). While students of political socialization were enthusiastic about the systematic study of the process by which children acquire attitudes and behaviors appropriate to their roles as future citizens, and the process whereby political values are transmitted from one generation to another, the field as a whole fell on hard times as it confronted criticisms and challenges targeting its theoretical perspectives, research methodology, and outcomes of investigation.

Those who were critical of the field argued that although political socialization assumed that politics is a learned behavior, learning theory was noticeably absent from the research (Landes 1976); that the system maintenance model adopted by political socialization rendered the field vulnerable to the charge of 
being conservatively biased toward favoring the status quo (Wright 1975); and that the assumptions and results of the large amount of research were inconclusive and unconvincing - there was scant evidence supporting inter-generational political stability and correlation between children's political attitudes and their adult political behaviors (Marsh 1971, 1975).

\section{Community Power Study}

Similar to political socialization, the field of community power study to a large extent was stimulated by an important book, Floyd Hunter's (1953) Community Power Structure. Hunter argued that an economic elite dominated the political understructure, composed of civic organizations, trade unions, and political parties. Important policies originated first in the elite to its own benefit; then they were transmitted to the understructure for public approval. The power structure in a community is like a pyramid with the economic elite on the top, the political understructure in the middle, and ordinary citizens at the bottom. Hunter's study was concentrated on a small group of the most powerful local leaders whom he selected by asking the opinion of prominent citizens. So his approach is referred to as "the reputational approach."

Another classical work in community power study is Robert A. Dahl's book, Who Governs? (1961). Dahl took a different approach from Hunter. Instead of concentrating on reputation to identify the most powerful leaders in a community, he claimed that studying the real decision-making process on matters of importance to the community revealed the community power structure. The approach is therefore called "the decision-making approach." Dahl concluded that community power was diffuse, and power coalitions varied from issue to issue. There was not a single, absolute, powerful elite that dominated community affairs. Elected officials, whose power rested on a collection of political interest groups and individuals whom Dahl called "the political stratum," were responsible for most of the important decisions. The majority of the citizens directly or indirectly influenced the decision-making process by choosing to actively participate in the political stratum or by simply casting vote.

From the very beginning, the reputational and decision-making approaches disagreed about their findings. Those who followed the reputational approach held an "elitist" view that American politics was in reality not democratic and an economic elite was dominating the political agenda. In contrast, those who believed in the decisionmaking approach maintained a "pluralist" view that American politics was democratic and no single economic elite was dominating the scene. There has been debate between the elitist school and the pluralist school ever since.

Researchers have conducted their studies within those two paradigms, either confirming or questioning one school or the other. ${ }^{4}$ The result was that at last, as one scholar in the field observed, the academic study of community power was not so much about realworld politics as it was about "the writings of scholars, and what they say they have found, and whether we ought to believe them or not, and why" (Polsby 1980, xi-xii).

Like political socialization, community power study was a very popular field for some time. Because power is such a fundamental concept in political science, community power study was regarded in a sense as political science per se, and scholars throughout the discipline followed the development in the field with great interest (Ricci 1980). However, the field did not retain its strength, and interest faded rapidly. By 1976 an observer commented that community power as a special field "is passe" (Walton 1976), and another observation asserted that "work on community power as an identifiable scholarly enterprise became less fashionable and influential as the 1970 s wore on" (Ricci 1980). ${ }^{5}$

\section{The Rapid Rise and Fall as Reflected in the Distribution of Publications Over Time}

Fashion as a social phenomenon has been studied by sociologists. ${ }^{6}$ Blumer pointed out that fashion was not only limited to social and cultural aspects. It also existed in the intellectual sphere:

Its presence can be seen in the history of modern philosophy. It can be observed at work in the realm of political doctrine. ... That this is true of the social and psychological science is perhaps more readily apparent. . . . To limit it, or to center it in, the field of costume and adornment is to have a very inadequate idea of the scope of its occurrence (Blumer 1969).

Unfortunately, to date, the study on fads in social science has been very limited. There have been very few systematic inquiries on the subject, and no theories or sophisticated analytical tools have been developed. One example of investigating fads in natural science is Penrose's (1952) study of thallium therapy of skin diseases, in which the investigator established the distribution pattern of journal articles describing treated cases and critical papers over a 26-year period to show that the therapy was a "craze" (Penrose 1952, 18-22).

The simplest and most direct way of evaluating the vitality of an academic field, as Penrose has done, would be to examine the strength and scope of its literature. How much research has been actually done and what pattern of distribution has the research formed over time? Publications are a dependable index of the scope and strength of the academic effort. ${ }^{7}$

The Social Science Index first listed political socialization as a category in 1967, but it was combined with political psychology. Starting from 1968, it has been a separate category. Therefore, the data are collected from 1967 until 1991. For 1967, since it was combined with political psychology, only those articles whose titles have the word "socialization" are included. For books, the data are derived from the computer index system, JANUS, of the Knight Li- 
FIGURE 1

Distribution of Journal Articles and Books in Political Socialization 1959-1991

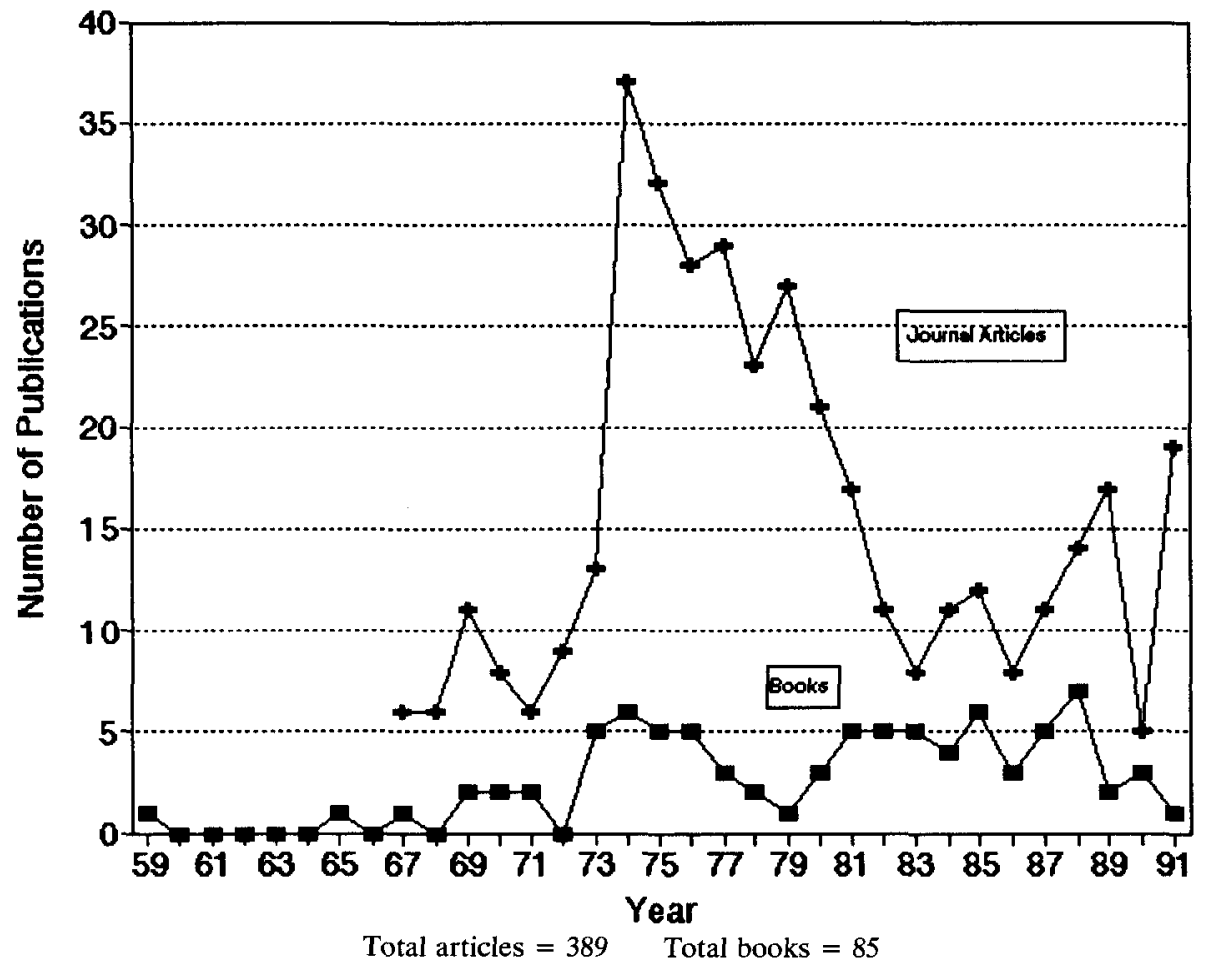

Source: 1. Social Science Index. New York: The H.W. Wilson Company.

2. JANUS computer index system, Knight Library, University of Oregon.

brary at the University of Oregon. Besides books under " political socialization," those under the category "children and politics" are also counted. Among them, for example, is Greenstein's Children and Politics (1965). The data on articles and books cover respectively 24 and 32 years.

$S S I$ began to list community power as a category one year after political socialization (in 1968). Another category, community leadership, is closely related to the subject, and the two categories are referred to each other in SSI. So the data include community leadership, which began to appear in SSI in 1962. For the same reason, books on community leadership are also included. A search through JANUS shows that Hunter's Community Power Structure is under community leadership, which proves the necessity of including this category. The data on articles and books cover respectively 29 and 38 years. The results of the investigation are shown in Figures 1 and 2 .

Figure 1 reveals that in terms of journal articles the field expanded rapidly in the mid-1970s with a peak in 1974. Then it began to slide steadily until a low point in 1983 . Although publication in the field made two small rebounds in 1989 and 1991, with a deep fall in 1990 , it has never regained strength.

The trajectory of the books shows a different pattern. After Hyman published his book in 1959 , no works immediately followed. From 1965, works began to appear until they reached a height in 1974 . After that, unlike the journal articles, the development was unsteady with several ups and downs.

The difference between journal articles and books is that while the former shows a clear pattern of expanding rapidly in the mid-1970s with a single peak, and dropping sharply after that, the latter does not form a single pattern. A possible explanation of this difference may be that it takes a longer cycle to finish a book-length project; therefore, books are less directly related to the changes occurring in the field. Journal articles, on the other hand, tend to be more sensi- tive to the changes in the academic climate. Consequently, journal articles may be a better indicator of the field.

Strikingly, the pattern of literature distribution of community power is very similar to that of political socialization. Figures 1 and 2 reveal that the developments of both fields followed almost the same pattern. They both originated in the $1950 \mathrm{~s}$, gradually progressed in the 1960 s, boomed in the mid1970 s, and declined sharply in the 1980s. Neither has regained the same vitality it experienced in its heyday.

The differences lie in that (1) community power journal publication did not even show any signs of rebound after the fall, while political socialization did have two rebounds in 1989 and 1991; and (2) books are more significant in community power than in political socialization, the ratio of journal articles to books being 2.95:1 in the former, and 4.58:1 in the latter. The second difference may help to explain why in community power the distribution in books follows approximately the same pattern as journal articles, while in political socialization it does not.

One thing that we need to be aware of in viewing the distribution of the journal articles is that many articles were contributed by "onetime" authors. These authors published one article and were never heard from afterwards. To get a more accurate picture, I have excluded those "first time" authors from the data, including only those who have published at least twice. Figures 3 and 4 show the result.

Excluding the first timers, Figure 3 differs from Figure 1 in that two peaks, instead of one, emerge in 1974 and 1977 . More importantly, the rebounds in 1989 and 1991, shown in the first figure, disappear. This indicates that the rebounds were mainly a product of works by the one-timers. It is clear that the same pattern holds in both figures. That is, the field kept its strength from 1974-1980; then it sharply declined, and never revitalized itself. The same is true of community power (see Figure 4).

In studying intellectual fads in 
FIGURE 2

Distribution of Journal Articles and Books in Community Power 1953-1991

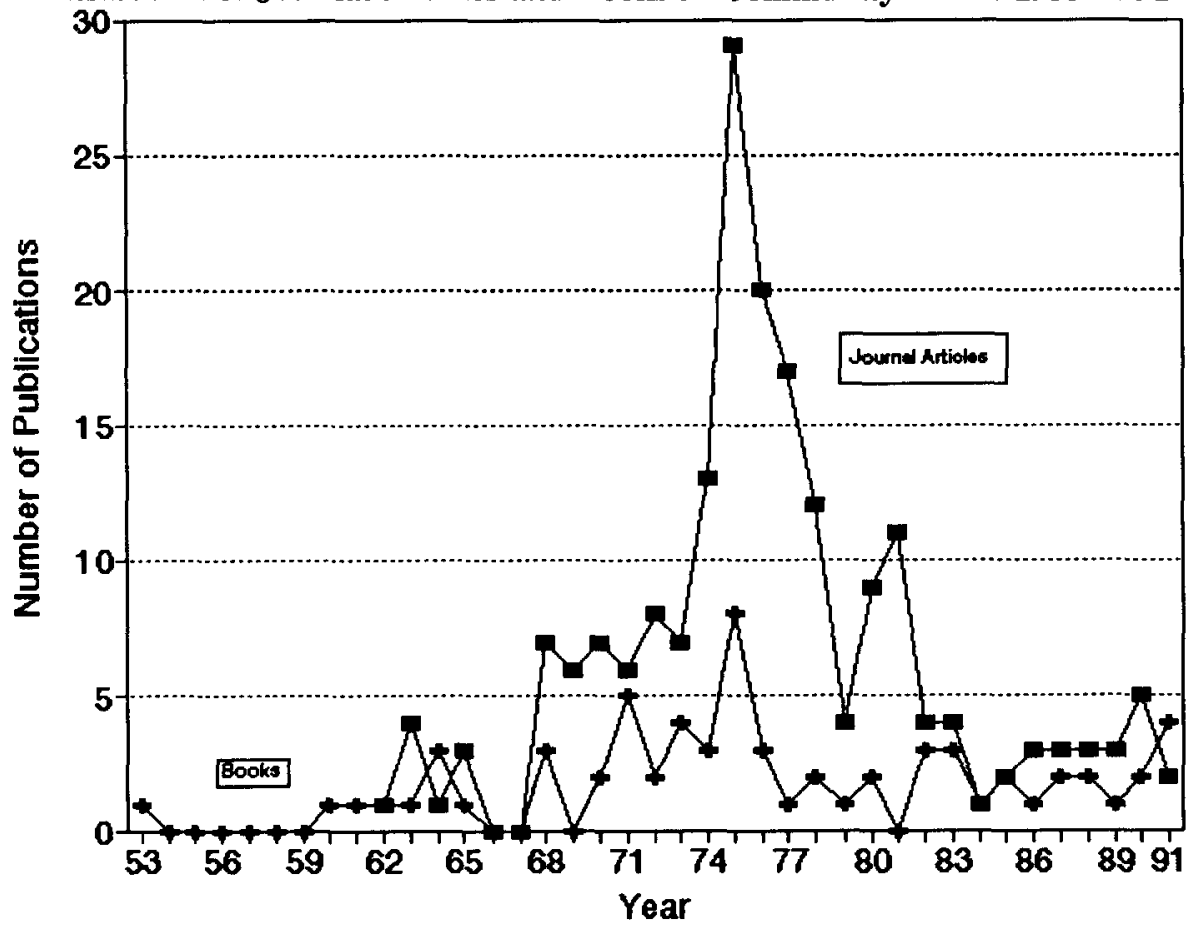

Total articles $=195 \quad$ Total books $=66$

Source: See Figure 1.

science, Penrose observed that a fad is marked by certain phases. The first phase is a latent period during which the idea originates, but does not spread. Then during the second phase the idea spreads rapidly, and it sometimes may develop an explosive character. As the market becomes saturated, the speed of the wave starts to slacken, and the fad enters its third phase. The fourth phase is distinguished by the development of mental resistance against the idea, and enthusiasm becomes weaker. In the final phase, if the idea does not disappear completely, it remains stagnant. The idea may be kept alive by a few enthusiasts and remain latent to bloom again in favorable circumstances (Penrose 1952, 1822). Reflecting on the cases of political socialization and community power with Penrose's argument in mind, one would have no difficulty identifying these characteristics.

The general distribution curve seems to concur. After a boom from the mid-1970s through the early 1980 s, political socialization and community power research both suffered a serious decline. There is no evidence, at present,

FIGURE 3 Excluding One-Time Authors

Source: See Figure 1. that either is regaining its strength. At this point, we can conclude, based on our data, that political socialization and community power reflect a tendency of intellectual fads: neither remained an active field of study in political science, and interest has long declined.

\section{The Tendency of Fads in Political Science}

The rise and fall of a distinct field in political science depend on "a variety of circumstances" (Wiarda 1985). It is generally hard to distinguish a single force that stands behind the change. Variables concerning the particular field, the nature of the discipline, historical context, academic and nonacademic aspects, etc., all influence the process. The following analysis tries to formulate some explanations that, rather than focus on factors within the faddish fields, are based on factors related to the discipline of political science.

\section{Fads Situated in a Fragmented Discipline}

The particular character of a discipline might affect the extent and

Distribution of Journal Articles in Political Socialization 1967-1991,

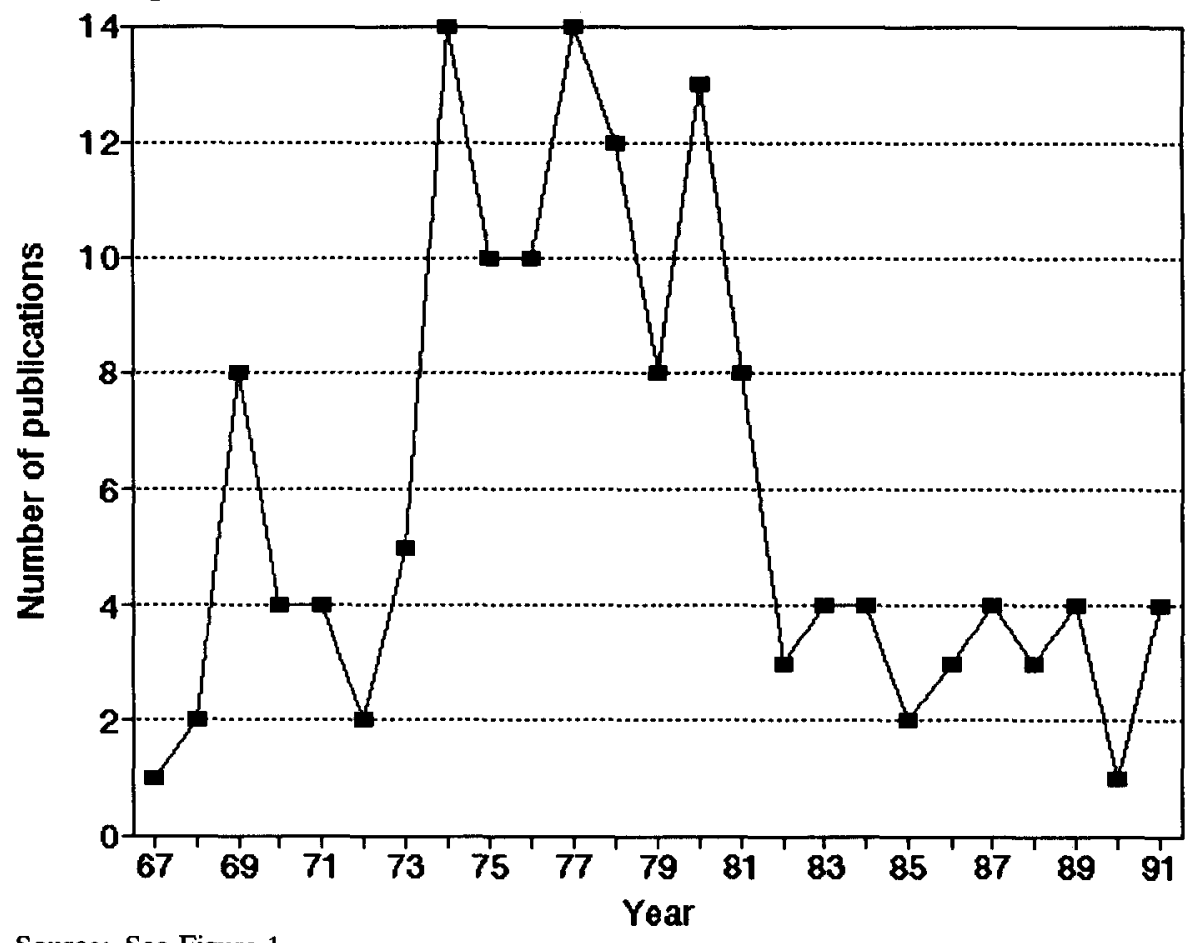
. 


\section{FIGURE 4}

Distribution of Journal Articles in Community Power 1962-1991, Excluding One-Time Authors

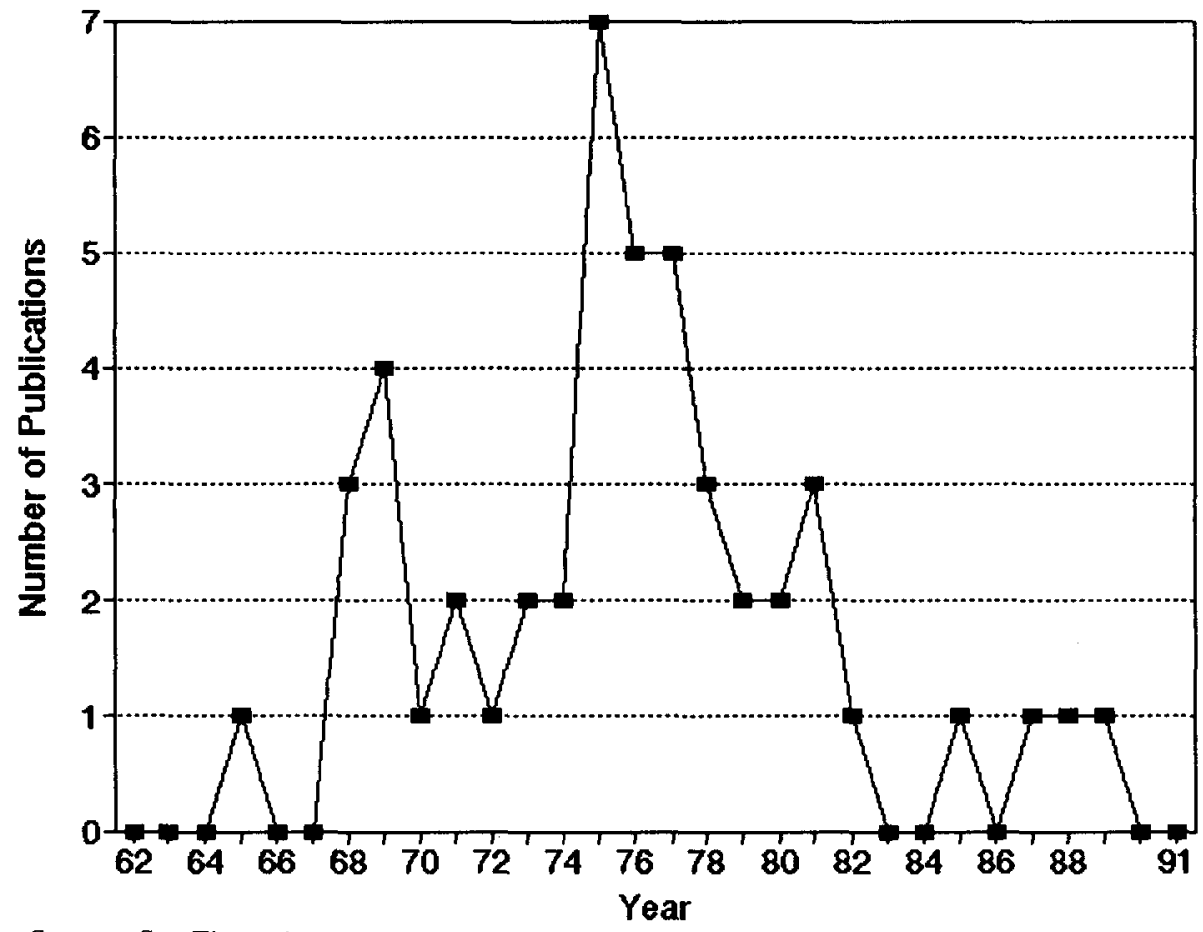

Source: See Figure 1.

pattern of fads within it. There are at least two characteristics of the political science discipline that are closely related to the occurrence of fads within the discipline. The first one, as is discussed at the beginning of this paper, is the fragmented nature of the discipline. Intellectual fads, if not the total consequence of the fragmentation, are intimately associated with it.

In assessing the state of the political science discipline, Raymond Seidelman stated that the "postbehavioral era," extending from the mid-1960s, is characterized more by what it is opposed to than by a common agreement on the nature of political science or its relations to the polity. Numerous approaches, subfields, and ideologies have emerged to give room to everyone (Seidelman 1985, 189). Many other observers point out that there is no agreed-upon body of knowledge in political science (Hacker 1967, 147); that there is no predominant paradigm in the discipline (Shapiro 1990); that political scientists lack a shared purpose (Somit and Tanenhaus 1982, 3); that political scientists are not very concerned with continuity (Lane 1972); and that the discipline is full of "small conversations," which are so specialized that they are unintelligible to the public and people in other academic communities (Ricci 1984, 299).

The fragmentation of the discipline has resulted in dispersion. As Seidelman argued, this dispersion has produced various academic "cul-de-sacs and enclaves in which each method, each approach, and each paradigm is awarded with its own self-contained journals, conference groups and subfields" (Seidelman 1985, 223). Under these circumstances, critiques of each other's research has not led to any "findings" that have been accepted by the academic community (Hacker 1967, 147). Practitioners tend to focus on "small and sharply delineated problems"' (Shapiro 1990). The discipline is dominated by "issue networks" and "iron triangles" (Almond 1988), and is troubled by "perpetual new beginnings" that are repeating efforts with variations on a theme (Seidelman 1985, 14). The dispersion thus has created a favorable climate not only for the existence of "cliques, coteries, and lone wolves talking past one another or to themselves" (Hacker $1967,147)$, but also for the emergence of novel approaches, methods, issues, problems and fields. The situation definitely nurtures the advent of intellectual fads.

Another aspect of the fragmentation of the discipline that affects the phenomenon of fads is the lack of consensus among political scientists with respect of research priorities, methods, and findings. Among other observers, Theodore Lowi noticed the low level of consensus in the discipline, and he believed that this was because political scientists did not share a common political experience (Lowi 1985).

Whatever the direct reason for the low level of consensus among political scientists, it is an expression of the fragmentation of the discipline, and likely to be related to fads. As defined above, intellectual fads refer to the situation in which an approach or a field of study rises quickly and attracts much attention, but loses popularity after a period of time and declines sharply. In short, an idea gains fame suddenly but does not retain vitality. There are many reasons why a field does not flourish after the initial boom. One of the answers may be related to the lack of a certain degree of consensus in the field. A framework of general consensus is one of the preconditions that a field will develop strongly.

As Somit and Tanenhaus argued:

If a discipline is to flourish, its practitioners must be in general agreement about their subject matter, their techniques, and the interests and behavior appropriate to the practice of their profession (Somit and Tanenhaus 1982, 50).

A study in sociology has found that journal rejection rates, instead of simply being a function of journal space, are closely correlated with interdisciplinary variation in academic consensus. There tends to be a higher rejection rate in social sciences, where consensus is low, than in natural sciences, where consensus is relatively high (Hargens 1988). While Hargens's 
unit of analysis is the disciplines, we may further assume that the same is true within the discipline. Low level of consensus leads to a higher rejection rate of journal articles for certain fields. As more journal articles are rejected, the field will ultimately decline.

\section{Politics, Scholarship, and Ideology ${ }^{8}$}

Another characteristic of political science that is closely related to the occurrence of fads is what Ricci frames as a circle in which political scientists constantly move among three poles of concern-the importance of politics, the imperative of studying politics in a scientific way, and the commitment to preserving democracy. According to Ricci, political scientists begin in the first pole by selecting issues open to research, move to the second in order to study them appropriately, and find later that the findings do not necessarily foster democracy. They then return to the first pole, hoping that repeated efforts will produce satisfactory outcomes (Ricci 1984, 24-5).

This continual cycle of academic endeavor, the belief in the inherent eminence of politics, and the incongruity between commitments to pure scientific research and ideological issues, in a way determine that the discipline as an intellectual enterprise always has the tendency to consciously explore new issues, redefine old issues, and search for more "scientific" approaches. In this situation, it is no wonder that ideas come and go quickly.

Although there has been an effort in political science to separate facts from values, the trends in political science have indicated that it is both a science of politics and a science for politics. As Almond contends, "There is no political science in the positivist sense, that is, a political science separable from ideological commitment" (Almond 1988). In the same line of thought, Hacker argued that political scientists must abandon the hope that "political analysis can be either objective or scientific" (Hacker 1967, 147). Even if political scientists can separate facts from values in their research, the ultimate purpose of studying politics is valuebased.

This fact has dual implications with respect to fads. First, ideologies are not static. Different eras may have different dominant ideological concerns, and these various ideologies may favor, or object to, distinctive sets of ideas in a given historical context. Ideas consequently rise and fall, giving opportunities for fads to arise. Second, as a consequence of the concern over serving an ideological purpose, political science has to take concrete political issues into its realm of inquiry. This would create many new fields. However, the real political world is unpredictable. Issues may be no longer in the center after a certain period. Accordingly, intellectual interest wanes, and the field becomes a fad.

There is a contrast between the study of political philosophy and current political matters. As long as political scientists are committed to both, there is always a tendency for fads, for the real world never stops generating new problems. For example, at this moment, it seems that the issues of international environmental politics, ethnic conflicts, regional economic blocs, and the impact of a viable "third" candidate on American presidential election are likely to become "hot", following the Rio earth summit, Yugoslavia, the North American Free Trade Agreement and the European economic integration, and Ross Perot.

\section{An Economic Model}

In addition to the idiosyncrasy of political science, the sociology of the discipline is also worth exploring in studying intellectual fads. David Ricci argues that within political science there exists a "repute system," which takes the form of journals, conventions, and scholarly writings, and which sanctions individual works by accepting some for publication in highly ranked journals, some in lesser journals, and rejecting others entirely. The repute system results from association among colleagues and produces "vocational knowledge" that is exchanged and shared by like-minded practitioners (Ricci 1984, 264-5). ${ }^{9}$

Publication is one of the ways the repute system sanctions the discipline. It is no secret that publication, particularly in prestigious journals, is seen as a sign of success and greatly influences decisions such as tenure and salary (Giles et al. 1989). Researches by some economists have found that the number of articles published is closely related to faculty salary.

For example, Tuckman discovered that those who have published articles are likely to receive a higher salary than those who have not (Tuckman 1976, 76). Similar findings indicate that published research has a great effect on earnings (Hanser, Weisbrod, and Strauss 1978). Furthermore, it was found that not only did the number of articles published affect a faculty member's salary, but the quality of the research (measured by citation) was also significantly related to his/ her salary. The latter had even a greater effect (Hamermesh, Johnson and Weisbrod 1982).

We can assume that intellectuals are rational beings who act in their own self-interest. The concern over self-interest in some sense helps the development of a fad, which in turn expands the opportunity to maximize self-interest. As Blumer (1969) argued, the adoption of fads is a calculating act on the part of the individual. Scholars, in some sense, are intellectual entrepreneurs. Like other entrepreneurs, they seek the greatest return for the smallest cost. Beyond concerns over promotion of knowledge (which, no doubt, many share), the desire for recognition, financial security, and fame must be considered in analyzing their activities.

Yet which intellectual enterprises are more likely to maximize the return? The answer has to be "a new field," especially one that appears to be promising and fashionable, namely, a fad. As we argued above, fragmentation and concern over politics, scientific inquiry, and ideology tend to stimulate new fields of study in political science. The advantage for an individual 
researcher to be engaged in a new field is that the competition tends to be low.

In an unestablished field, what is called "cumulative advantage"10 usually does not exist. Cumulative advantage refers to the situation in which those scientists who have achieved recognition find it easier to get access to research facilities, grants, free time, positions in famed institutions, etc., hence more opportunities for publication. As a cohort of scientists gets older, cumulative advantage produces increasing inequality among them (Allison et al. 1982). This makes it more difficult for those who have not achieved cumulative advantage to compete with the established authorities. Given the fact that some journals simply do not accept unsolicited manuscripts, namely, they only recognize cumulative advantage, the difference between advantage and disadvantage becomes more apparent. In a new field, however, the chance of a high return is larger for most intellectual entrepreneurs.

A new field may suddenly thrive for a variety of reasons. One critical condition, however, as Blumer pointed out, is the presence of distinct figures "who espouse one or another of the competing models" (Blumer 1969). The prestige of such persons gives the field a sense of importance and legitimation, and makes it appear to be appealing. Hyman, Hunter, and Dahl were perfect examples of such figures. A lot of excitement would be aroused, but the point is that even the prestigious figures do not have an absolute say in the new field. No one (including journal editors) can claim matter-of-course qualification to pass judgments on research. It is thus relatively easy to have research published. In addition, because of the excitement that the field arouses, it is easy to get foundation funding. In other words, the cost is low, and the return is high.

Under these circumstances, the incentives to enter the field are great. It is natural that many researchers do. People generate research, publications, conventions, panels, critiques, and counter-critiques. Assertions are advanced, attacked, and salvaged, forming what Merelman (1968) called a "dialectical pattern." The enthusiasm thus creates a fad by not only producing a large amount of publication, but also citations among members engaged in the fad. It is interesting to note that whether and how often scholars' works have been cited is found to have a major impact on faculty members' salary, even a greater effect than publication per se (Hamermesh et al 1982). Thus, the enthusiasm helps practitioners in every possible way to secure a high return for a low cost. When the field is rising, a large number of people cannot resist the temptation to have their share, because they tend to overestimate the benefit and underestimate the cost.

As more and more intellectual entrepreneurs join in and the quantity of the academic goods increases, the chance for an individual researcher to be published becomes smaller and competition gets tougher. In addition, a few scholars gradually gain cumulative advantage, which makes it even harder for others to compete. As a result, the marginal benefit of doing research in the field diminishes, and the marginal cost increases. The field at this stage becomes saturated.

Then comes the situation known as "diminishing marginal utility" in economics, resulting from the increase of the quantity of a good in a given period. ${ }^{11}$ As benefit keeps diminishing and cost keeps increasing, enthusiasm abates and interest wanes. At this moment, the intellectual enterprise, like a firm in the business world, reaches the "shutdown point," defined as the level of output below which the firm would not operate because the loss from operating is greater than that of shutting down.12 If this happens, the field declines sharply, and the fad is over. The utility of this model, needless to say, is that it is not limited to fads in political science. It can be generalized to intellectual fads in general.

Fads are particularly attractive to young scholars, because they usually are more desperate to establish themselves for reputation, tenure, promotion, and financial security, than well-established older scholars. Young faculty members are in a less disadvantageous position in a new field because authority is not yet fully instituted.

The probability for a newcomer to have an article accepted by a journal is likely to be higher in a new field than in an established one, especially when some journals only accept solicited manuscripts from established authorities. Young scholars starting their career thus unconsciously play a big role in fads. The marginal value of publication is smaller for older and wellpublished professors than for beginners in the field (Tuckman 1976, 90).

The point can be framed in the following way. Suppose the marginal value (MV) of publication is the amount of dollar value multiplied by the number of years before the faculty member retires. Even if the absolute dollar value of an article for a senior professor is higher than that for a young assistant professor, the MV would still be lower. For example, if a professor will retire in five years, the MV for a published article at $\$ 500$ would be $\$ 500 \times 5=\$ 2,500$.

In contrast, for an assistant professor retiring in 30 years, the MV of an article at a lower absolute dollar value ( $\$ 200$ ) would be $\$ 200$ $\times 30=\$ 6,000$. Thus, young scholars are expected to have more incentives to participate in fads. A few of them successfully accumulate advantage and hang on long after the fad is gone, or simply transfer the advantage they have built to another field. The majority try unsuccessfully and leave for something else.

This argument, however, is not to claim that young scholars deliberately pursue the financial gains of early publication. Usually, they are unconsciously engaged in self-interest maximization without knowing the marginal value of their publication, which is more a natural consequence than a calculated goal. Indeed, they are more likely to consciously seek informal rewards, such as the recognition of peers, satisfaction of intellectual achieve- 
ment, and the feeling of being on the cutting edge.

While we have tried to identify some disciplinary and external determinants of fads in political science by way of the discipline itself and a proposition based on the sociology of science, it would be difficult to exhaust the factors that shape the course of intellectual fads. Other causes may well include social psychology, changes in other social sciences, foundation funding, political context (e.g., stability vs. upheaval), and economic conditions (e.g., growth vs. recession).

\section{Conclusion}

Both political socialization and community power had their bright days, but they were eclipsed quickly, leaving promises unfulfilled and problems unsolved. Why did such academic fads happen? Particularly, why did they happen in the political science discipline? By exploring these questions I have attempted to shed some light on the mechanism of intellectual inquiry, the sociology of scientific research, the characteristics of the discipline, and the relationship between political science and politics. Realizing that the phenomenon of intellectual fads has not been adequately studied, this paper tries to formulate some explanations of fads as a general occurrence in academic life and as related to political science.

Using quantitative data on publication, the study demonstrates that both political socialization and community power study are cases of what we conceive as fads. They rose rapidly, attracted much attention in the discipline, and declined sharply. Various complex factors contribute to the phenomenon. While realizing that theorizing is difficult, if not impossible, in this regard, I have tried to identify several factors that are crucial to the development of fads. The results of the investigation suggests that the existence of fads in political science is related to the fragmentation of the discipline, expressed in dispersion and lack of consensus; to the circular movement of political scientists among politics, scholarship and ideology; and to political scientists' commitment to both scientific study and the idea of democracy.

Fads in intellectual enterprises are also associated with the academic reward system. Aspiration for publication motivates faculty members, especially young faculty members, to seek the largest return in a rapidly rising new field, and the same motivation makes researchers leave the field when the cost gets high.

Several clarifications need to be made before concluding. First, as it is said before, the causes of fads are manifold and complex. The study does not claim that it exhausts all the options. Also, it is highly possible that the reasons for fads do not have to be eminently rational. Accidental forces, such as timing, political and economic contexts, and historical incidents can affect their development. Besides, it needs to be noted that there are differences between "fads" in general and some "particular fads." Thus, a generalization may not be plausible.

Second, the study is not claiming that those who are engaged in fads are consciously promoting a fad. It is true that individuals act in their self-interest, but fads as collective behavior are not consciously created. After all, a fad is not known as a fad until it is over.

Third, the study tries not to pass a normative judgment on fads. The analysis has mainly concentrated on how the discipline and other factors affect the development of fads, rather than how fads affect the discipline as a scientific enterprise. Though it is desirable to do so, it is beyond the scope of this study. Some people may argue that fads are detrimental to normal scientific research and the efforts to find truth. Others may not think they are harmful. No matter what people's opinions are toward intellectual fads, fads are an objective reality. As long as there are scientific endeavors, there will always be a tendency towards fads.

\section{Notes}

*The author would like to thank Professors John Orbell, John Dryzek, and William Mitchell at the department of political science, University of Oregon, for their critical comments and suggestions on the conception and execution of this paper.

1. See, for example, Andrew Hacker. 1967. "The Utility of Quantitative Methods in Political Science." In Contemporary Political Analysis, ed. James C. Charlesworth. New York: Free Press; Robert E. Lane, 1972. "To Nurture a Discipline." (APSA presidential address) American Political Science Review 66:164-82; David Ricci. 1984.

The Tragedy of Political Science: Politics, Scholarship, and Democracy. New Haven, CT: Yale University Press; Raymond Seidelman. 1985. Disenchanted Realists: Political Science and the American Crisis, 1884-1984. Albany, NY: State University of New York Press; Ian Shapiro. 1990. "The Nature of Contemporary Political Science: A Roundtable Discussion." PS 23:34-43; and Albert Somit, and Joseph Tanenhaus. 1982. The Development of American Political Science. New York: Irvington Publishers.

2. Webster's New World Dictionay. 3rd college ed. 1988. New York: Simon \& Schuster.

3. Strictly speaking, Hyman's book was not the first work on political socialization, though his was the first to adopt that term. In 1931, Charles Merriam published The Making of Citizens: A Comparative Study of Methods of Civic Training (Chicago: The University of Chicago Press). Merriam believed that the precondition for the preservation of democracy was the existence of welleducated citizens led by reasonable leaders. Civic education was thus viewed by him as a means of instilling political virtue into citizens. However, Merriam's appeal did not turn into a fad. The reason may be that political scientists then were preoccupied by the concern over the depression, and few people were interested in studying how children acquire their political orientation.

4. While very few studies on community power avoided taking sides in the debate, there were some exceptions. One example is Robert E. Agger, Daniel Goldrich, and Bert E. Swanson. 1964. The Rulers and the Ruled: Political Power and Impotence in American Communities. New York: John Wiley \& Sons.

5. For some good reviews of community power study field, see Richard M. Merelman. 1968. "On the Neo-Elitist Critique of Community Power." American Political Science Review 62:451-60; David Ricci. 1980.

"Receiving Ideas in Political Analysis: The Case of Community Power Studies, 19501970."Westem Political Quarterly 33:45175 , and his 1984 book, The Tragedy of Political Science: Politics, Scholarship, and Democracy. New Haven: Yale University Press, 265-75; and John Walton, 1976, "Community Power and the Retreat from Politics: Full Circle After Twenty Years?" Social Problems 23:292-303.

6. For example, B. E. Aguirre, et al. 1988. "The Collective Behavior of Fads: 
The Characteristics, Effects, and Career of Streaking." American Sociological Review 53:569-84; Herbert Blumer. 1969. "Fashion: From Class Differentiation to Collective Selection." Sociological Quarterly 10:275-91; L. S. Penrose. 1952. On the Objective Study of Crowd Behavior. London: H. K. Lewis; and Ralph H. Turner and Lewis M. Killian. 1957. Collective Behavior. Englewood Cliffs, NJ: Prentice-Hall.

7. It needs to be noted that, after a research project is completed, it normally cannot be published immediately. Publication in this circumstance may lag development. However, if the data are collected for a long period, this would not affect the validity.

8. This phrase is adapted from David Ricci. His original phrase is "politics, scholarship, and democracy." Ricci uses this subtitle for his book to indicate "the subject of political science inquiry," "the way in which inquiry is conducted by the discipline," and "the entity that political studies in America presumably serve" (Ricci 1984, 3).

9. Ricci borrowed the terms "repute system" and "vocational knowledge" from Philip H. Melanson. 1975. Political Science and Political Knowledge. Washington: Public Affairs Press, 95-98.

10. For research on cumulative advantage, see Robert K. Merton. 1942. "The Normative Structure of Science." Reprinted in Robert K. Menton. 1973. The Sociology of Science. Chicago: University of Chicago Press; 1968. "The Matthew Effect of Science," Science 159:56-63; and Paul A. Allison et al. 1982. "Cumulative Advantage and Inequality in Science." American Sociological Review 47:615-25.

11. For the concept of diminishing marginal utility, see, for example, Daniel R. Fusfeld. 1988. Economics: Principles of Political Economy. Glenview, IL: Scott, Foresman and Company. 321-22.

12. Fusfield 1988, 368.

\section{References}

Allison, Paul A., et al. 1982. "Cumulative Advantage and Inequality in Science." American Sociological Review 47:615-25.

Almond, Gabriel. 1988. "Separate Tables: Schools and Sects in Political Science." PS 21:828-40.

- 1990. "The Nature of Contemporary Political Science: A Roundtable Discussion." PS 23:34-43.

Biographical Directory of American Political Science Association. 1988. American Political Science Association.

Blumer, Herbert. 1969. "Fashion: From Class Differentiation to Collective Selection." Sociological Quarterly 10:275-91.

Conell, R. W. 1972. "Political Socialization in the American Family: The Evidence Re-examined." Public Opinion Quarterly 36:323-33.

Dahl, Robert A. 1961. Who Governs? Democracy and Power in an American City. New Haven: Yale University Press.
Davies, J. C. 1905. “The Family's Role in Political Socialization." The Annals 361: 11.

Gilberg, Trond. 1975. " Romania: In Quest of Development." In Political Socialization in Eastern Europe: A Comparative Framework, ed. Ivan Volgyes. New York: Praeger.

Giles, Micheal W., et al. 1989. "Political Scientists Journal Evaluation Revisited." PS 22:613-17.

Greenstein, Fred I. 1965. Children and Politics. New Haven: Yale University Press.

Greenstein, Fred I., and Nelson W. Polsby, eds. 1975. Handbook of Political Science. Reading, MA: Addison-Wesley Publishing Company.

Hacker, Andrew. 1967. "The Utility of Quantitative Methods in Political Science." In Contemporary Political Analysis, ed. James Charlesworth. New York: Free Press.

Hamermesh, Daniel S., George E. Johnson, and Burton A. Weisbrod. 1982. "Scholarship, Citations and Salaries: Economic Rewards in Economics." Southern Economic Journal 49:472-81.

Hanser, W. Lee, Burton A. Weisbrod, and Robert P. Strauss. 1978. "Modeling the Earnings and Research Productivity of Academic Economists." Journal of Political Economy 86:729-41.

Hargens, Lowell L. 1988. "Scholarly Consensus and Journal Rejection Rates." American Sociological Review 53:139-51.

Hunter, Floyd. 1953. Community Power Structure: A Study of Decision Makers. Chapel Hill, NC: The University of North Carolina Press.

- 1980. Community Power Succession: Atlanta's Policy-Makers Revisited. Chapel Hill, NC: The University of North Carolina Press.

Hyman, Herbert H. 1959. Political Socialization: A Study in the Psychology of Political Behavior. Glencoe, IL: The Free Press.

Landes, Ronald G. 1976. "The Use of Role Theory in Political Socialization Research." International Joumal of Comparative Sociology 17(1-2):59-72.

Lane, Robert E. 1972. "To Nurture a Discipline." APSA presidential address. American Political Science Review 66: $164-82$.

Lowi, Theodore J. 1985. Forward to Raymond Seidelman. Disenchanted Realists. Albany, NY: State University of New York Press.

Marsh, David. 1971. "Political Socialization: The Implicit Assumptions Questioned." British Journal of Political Science 1:453-65.

- 1975. "Political Socialization and Intergenerational Stability in Political Attitudes." British Journal of Political Science 5:509-16.

Merelman, Richard M. 1968. "On the NeoElitist Critique of Community Power." American Political Science Review 62: 451-60.

Merriam, Charles Edward. 1931. The Mak- ing of Citizens: A Comparative Study of Methods of Civic Training. Chicago: The University of Chicago Press.

Penrose, L. S. 1952. On the Objective Study of Crowd Behavior. London: H. K. Lewis.

Polsby, Nelson W. 1980. Community Power and Political Theory: A Further Look at Problems of Evidence and Influence. New Haven: Yale University Press.

Ricci, David. 1980. "Receiving Ideas in Political Analysis: The Case of Community Power Studies, 1950-1970," The Westem Political Quarterly 33:451-75.

. 1984. The Tragedy of Political Science: Politics, Scholarship, and Democracy. New Haven: Yale University Press.

Schonfeld, William R. 1971. "The Focus of Political Socialization Research: An Evaluation." World Politics 23:544-78.

Seidelman, Raymond. 1985. Disenchanted Realists: Political Science and the American Crisis, 1884-1984. Albany, NY: State University of New York Press.

Shapiro, Ian. 1990. "The Nature of Contemporary Political Science: A Roundtable Discussion." PS 23:34-43.

Social Science Index. New York: The H. W. Wilson Company.

Somit, Albert, and Joseph Tanenhaus. 1982. The Development of American Political Science: From Burgess to Behavioralism. New York: Irvington Publishers.

Tuckman, Howard P. 1976. Publication, Teaching, and the Academic Rewards Structure. Lexington, MA: D. C. Heath.

Volgyes, Ivan, ed. 1975. Political Socialization in Eastem Europe: A Comparative Framework. New York: Praeger Publishers.

Walton, John. 1976. "Community Power and the Retreat from Politics: Full Circle After Twenty Years?"' Social Problems 23:292-303.

Wiarda, Howard J. 1985. “Comparative Politics Past and Present." In New Directions in Comparative Politics. ed. Howard J. Wiarda. Boulder, CO: Westview.

Wright, James D. 1975. "Political Socialization Research: The Primacy Principle." Social Focus 54:243-55.

\section{About the Author}

Yali Peng was born in Guizhou, China. He earned an M.Ed. in adult education at Oregon State University in 1989 and is currently a Ph.D. candidate at the department of political science, University of Oregon. He has recently published articles on privatization in East Europe and Japan's environmental diplomacy. 